\title{
Developing career management competencies among undergraduates and the role of Work-Integrated Learning
}

\section{DENISE JACKSON (Edith Cowan University) AND NICK WILTON (UWE Bristol)}

\begin{abstract}
This paper explores undergraduate capabilities in career self-management and the influential role of Work-Integrated Learning (WIL). Career management competencies are an important aspect of individual employability and impact on wellbeing, graduate job attainment and long-term career success. Enhanced competencies among graduates can assist Faculty in achieving strong employment outcomes and support industry partners who wish to employ graduates able to self-manage their career pathways effectively amid flatter organisational structures and greater employee mobility. Our findings indicate that business undergraduates at a UK and Australian university consider themselves reasonably proficient in career selfmanagement yet variations exist across the different dimensions of self-awareness, opportunity awareness, decision-making learning and transition learning. Participation in work placements and study and employment characteristics influenced certain elements of career self-management. Our study highlights the importance of nurturing career management competencies in undergraduates and we discuss strategies, particularly in relation to WIL, which may promote effective career self-management.
\end{abstract}

\section{Keywords}

Career management competencies; Work-Integrated Learning; employability; employment. 
Amid continued economic uncertainty and a soft graduate labour market (Ross 2012; Tomlinson 2012), strategies for developing employable graduates are of significant concern to higher education (HE) providers worldwide. Graduate employability is a multifaceted concept shaped by many influences including disciplinary expertise, non-technical skills, and life and work experience (Dacre Pool and Sewell 2007). Policies and practices to produce employable graduates have typically emphasised the development of non-technical skills (Holmes 2013), such as communication, self-management, self-awareness and problem solving (AAGE 2013). However, the changing nature of graduate careers, reflecting trends in organisational restructuring and the emphasis on individual responsibility for career development (Jain and Jain 2013), have acted to influence what constitutes a work-ready graduate and increases the pressure on HE providers to produce graduates who are both adequately skilled but also adept at making informed career choices, navigating a range of job opportunities and articulating their strengths and abilities in a highly competitive labour market (Coetzee and Beukes 2010). University-wide efforts in fostering graduate employability must therefore extend to the development of career management competencies.

Career management competencies span the formulation of informed career goals, understanding labour market conditions, job search skills, locating and selecting relevant learning opportunities (Bridgstock 2009; Eby, Butts, and Lockwood 2003; King 2004) and professional networking (see de Janasz and Forret 2008; Gerard, 2012). For undergraduates, the benefits of proficiency in career management enhances self-efficacy (Raelin et al. 2011), encouraging individuals to focus on the expectations of their chosen profession and the identification of employment pathways early in their career (Watts 2006). Such capabilities also promote a lifelong approach to developing and maintaining employability among 
graduates (see Berdrow and Evers 2011), sometimes leading to enhanced graduate employment outcomes (Purcell et al. 2013).

Despite these potential benefits, career management competencies remain under-explored in respect of their precise nature, extent of development and determinants among undergraduates (Watts 2006). Enhancing current understanding will assist in identifying areas where undergraduates are less proficient and inform strategies for their development, an imperative given the documented gaps in graduate mastery of such competencies (Bridgstock 2009; Laker and Laker 2007).

Watts (2005) suggests that the development of career management competencies in HE is not adequately harnessed with concerns surrounding the extent to which existing provision engages students (Stevenson and Clegg 2011; Purcell et al. 2013). Work-Integrated Learning (WIL) has been considered as an alternative, or potentially complementary, platform for the successful development of career management competencies (see, for example, Pegg et al. 2012; Watts 2006). In the HE context, WIL represents the intersection of theoretical and practice learning (Orrell 2011) and a prominent aspect of the interface between university and industry. It provides students with a valuable learning experience centred on the integration of academic learning with 'real-world' work and encourages both industry feedback on individual capability and self-reflection (see Smith 2012). As such, it presents a valuable opportunity for developing student's awareness of the labour market and possible career pathways, as well as the necessary exposure to a relevant work setting to facilitate informed career choices (Usher 2012). 
We sought to develop current understanding of the extent to which undergraduates possess career management competencies and the degree to which they are influenced by individual and study characteristics and their participation in WIL. More specifically, our research

objectives were to: (i) gauge the extent of career management competencies among undergraduates; (ii) evaluate the role of WIL in the development of undergraduate career management competencies; and (iii) assess the variation in career management competencies by individual characteristics. We addressed the research objectives using data on business undergraduates studying in two different universities, one based in the UK $(N=136)$ and the other Australia $(N=344)$. We have structured the article to first provide a background review of relevant literature on career self-management, with a focus on undergraduates and new graduates. We follow this with an outline of the study's methodology, presentation of the results and then discuss implications of the findings for practitioners.

\section{Background}

\section{What are career management competencies?}

Career management encompasses career planning, the identification of career goals and pathways for achieving them, and career development, learning skills and competencies to achieve one's career aspirations (see Ayranci and Oge 2011). Smith et al. (2009) highlight the requisite ongoing nature of career management with the individual progressing through cyclical stages of self-awareness and resolution of career-related issues. Career management competencies are, therefore, inextricably linked with professional development planning (Watts 2006) with self-reflection being integral to the successful development of both (Pegg et al. 2012). 
There are a range of conceptual frameworks encapsulating competencies considered important for self-managing one's career. An established and widely used model (Watts 2006) is DOTS (Peterson, Sampson, and Reardon 1991) which underpins much of career management provision in HE providers (Evans 2008). The model comprises four dimensions: development of decision-making skills; opportunity awareness; transition learning - such as job-search skills - and self-awareness. Later, King (2004) developed a framework of career management competencies that comprised positioning, influence and boundary management behaviours, the development of which ensures individuals have the necessary contacts, skills and experience for their chosen career and is suitably equipped to influence gatekeepers in order to manage their career effectively. Hawkins and Winter's (1995) framework highlights self-awareness, self-promotion, access to opportunities, action planning, networking, decision making, negotiation, political awareness, coping with uncertainty, development focus and transfer skills.

We note that more recent literature emphasises establishing informed career goals and understanding local labour market conditions (Eby et al. 2003). Bridgstock (2009), for example, presents a model of graduate employability which highlights the importance of developing career management in undergraduates, including capabilities in analysing the labour market, successfully applying for positions, locating and selecting relevant learning opportunities and professional networking. Akkermans, Brenninkmeijer et al.'s (2013) empirically validated six constructs of career competencies: reflection on motivation, selfprofiling, work exploration, reflection on qualities, networking and career control. In Australia, the national Blueprint for Career Development framework was introduced to underpin career development programs and comprises 11 competencies across personal management, learning and work exploration and career building (see Hooley et al. 2013). 


\section{The importance of career management competencies}

On an individual level, career management helps to develop undergraduate understanding of their career options (Miller and Liciardi 2003) and encourages them to reflect on their career choices and pathway (Greenbank 2011). Drawing on the work of Holmes (2001), career management capabilities also contribute to the development of one's identity, as '... the type of work we do determines our social standing and status. It provides a means for 'placing' oneself, and for others to 'place' us, within society' (Evans 2008, 47). In the long term, there is evidence that career management competencies positively influence employee wellbeing, self-efficacy, goal achievement, resilience, personal growth and work-engagement (Akkermans, Schaufeli et al. 2013). Further, Adamson, Doherty and Viney (1998) stressed the relationship between effective career-self-management and 'the continuous construction and maintenance of a healthy self-concept, congruent with individuals' changing strengths and weaknesses, shifting beliefs and attitudes and future aspirations' (257).

There is also broad acknowledgement and documented evidence that career management influences individual employability (Potgieter 2012; Raemdonck et al. 2011) and 'how the individual perceives his or her opportunities in the labour market' (Berntson and Marklund 2007, 281). There is evidence, although Bridgstock (2009) argues somewhat limited, that skills in accessing and using relevant information on career roles, job applications and labour markets will positively impact on employment outcomes (Krug and Rebien 2011; Pegg et al. 2012). Increasingly competitive graduate labour markets (AGR 2013; AAGE 2013; Accenture 2013; Purcell et al. 2013), and developing patterns of global student mobility, (IEAA 2012) mean that effective career self-management has become ever more critical for graduate career success (Segers and Inceoglu 2012). 
Career management competency is also important for long-term career progression. In the context of increasingly complex and fragmented career paths (see Akkermans, Schaufeli et al. 2013) and a focus on career self-reliance (see Smith and Kruger 2008), skill in career management is required to generate and maintain career momentum, reduce the likelihood of dysfunctional job turnover through lack of person-job fit (Heaton et al. 2008) and enables personal development (Whitelaw 2010). Furthermore, Bridgstock (2009) summarises a number of broader economic benefits associated with effective career management including improved productivity, lower unemployment and reduced healthcare costs and crime rates from higher earnings. This discussion highlights the importance of our first research objective, to gauge the extent of career management competencies among undergraduates.

\section{Development of career management competencies}

The development of career management competencies in HE, often referred to as 'career development learning', can be structured as university-wide generic modules, customised units for certain schools or faculties or more bespoke options for particular programs or courses (Watts 2006). Stand-alone, extra-curricular initiatives, such as career fairs or seminars, can be delivered at key stages of study and target certain groups yet their irregularity and isolation from course curricular may deem them insufficient in developing career readiness (Sultana 2012). The need to infuse career management learning across the disciplinary curriculum, and early, is echoed by many (Bridgstock 2009; Pegg et al. 2012). Such early intervention is important as graduate recruiters shift talent acquisition to first and second year undergraduates; aiming to capture 'elite' students (Isherwood 2014) through internship and vacation programs. Greenbank (2011) also argues provision should be studentcentred and facilitative of effective decision-making rather than advising students what choices to make. 
Pegg et al.'s (2012), in their review of careers service provision in the UK, concluded that interaction among career experts and those responsible for the design and delivery of academic content - particularly if the service is expected to enhance employability - is critical. Benson, Morgan, and Filippaios (2014) consider the role of social media in cultivating career management among students, while AGCAS (2005) provide a useful review of suitable teaching and learning methods such as 'buzz-group' discussions, personal skill audits, role play scenarios such as interviews and peer reviews of resumes. Sultana's (2012) summary of career management learning in Europe indicated assessment was largely informal, formative and multi-modal. Interviews, self-assessment and competency assessment - including action planning - were popular, and there was extensive use of portfolios. The use of portfolios for self-reflection is strongly supported and is considered critical for self-awareness and the effective articulation of experience and capabilities to potential employers, particularly in non-technical skills (Berdrow and Evers 2011). Recent discussions of alternative approaches focus on the use of library services (Davey and Tucker 2011) case studies and lectures (Greenbank 2011) and embedded units or modules (see Evans 2008).

Unsurprisingly, employers are concerned with graduate career management competencies (Bridgstock 2009). Sagdic and Demirkaya (2009) cite a range of studies which suggest that many young people are not adequately planning their careers, particularly students from lower socio-economic backgrounds (Greenbank and Hepworth 2008), increasing the likelihood of poor employment outcomes upon graduation (Ayranci and Oge 2011). Undergraduates are failing to 'adopt a practical, proactive approach to their careers' (McKeown and Lindorff 2011, 311) and are not adequately engaging with career management activities (see Brown and Hesketh 2004; Greenbank and Hepworth 2008). 
This failure to adequately engage in career development activities may partly be attributed to ignorance. McKeown and Lindorff (2011) highlight the disparity between graduate expectations of the labour market and what they term as 'job search realities', with many undergraduates initially expecting a 'good job' upon graduation and unprepared for extensive job searches and the anxiety associated with ongoing career self-management (Perrone and Vickers 2003). However, this lack of preparedness cannot be solely attributed to a lack of student engagement. Many commentators believe existing career management provision in HE is not providing students with the necessary strategies or capabilities to realise employer expectations (McKeown and Lindorff 2011; Ng and Burke 2006; Pegg et al. 2012). Despite provision evolving from lengthy, individual guidance interviews to more bite-sized interventions that are wider in scope, such initiatives are criticised as continuing to focus on short-term employment outcomes (see Watts 2006). Further, these services most often assist those who need the least guidance and support with lower levels of take up among widening participation, mature and part-time students (Stevenson and Clegg 2011).

\section{Role of WIL}

Watts (2006) argues problem-based, active and student-centred learning are essential to the effective development of career management competencies, in addition to an authentic context that facilitates the simulation of work-related activities. He appraised student learning in the workplace as a significant contributor to career readiness, helping to prepare graduates who are often required to 'hit the ground running' once in employment. Similarly, Hooley (2013) notes that instead of being concerned with when career management is learned in an undergraduate context, rather the focus should be on where and in what context. Smith et al. (2009) advocate WIL as a valuable tool for nurturing reflection and planning while Raelin et al. (2011) posits enhanced career self-efficacy from WIL opportunities. The importance of 
employers' input into the learning and assessment of career management competencies, to add realism and credibility to content, is acknowledged by many (Bridgstock 2009; Gunn and Kaffman 2011; Jackson 2014).

The focus of WIL is the development of those competencies that facilitate lifelong learning, rather than disciplinary knowledge and skills (Usher 2012), the enhancement of workreadiness through developing non-technical attributes such as self-efficacy and effective team-working (see McIlveen et al. 2011; Smith and Worsfold 2013). WIL also acts to enhance students' understanding of the expected skills and task performance in their chosen profession (see Jackson 2014), empowers effective career decision-making and facilitates successful networking in one's chosen field (Bourner and Millican 2011).

Barriers remain, however, to the effective use of WIL to develop career management competencies. For instance, there is confusion over the different terminology applied to WIL and the different forms it can take, affecting stakeholder understanding of how it is enacted (Maertz, Stoeberl, and Marks 2014). Cleary et al. (2013) also highlight the potential lack of managerial support in the workplace that may be problematic for career development. The potential influence of WIL prompts our second research objective, an evaluation of the role of WIL in developing undergraduate career management competencies.

\section{Variations in career management competencies}

Demographic influence on the development of career management competencies is under explored (Jain and Jain 2013), particularly for groups other than established professionals and managers (Zhang 2010). This prompts our third research objective, assessing the variation in career management competencies by individual characteristics. Extant studies suggest 
contradictory evidence for the influence of age on career management competencies (see Gerber et al. 2009; Zhang 2010; Creed, Prideaux, and Patton 2005; Kujpers and Meijers 2012) and that exploring the influence of gender appears more focused on career success and career orientation (see, for, example Ashby and Schoon 2010; Gerber et al. 2009). Kuijpers and Meijers (2012) found that males were more competent in career exploration and networking. There is, however, evidence to suggest females are more adept at making career choices yet males are more certain of their decisions (Patton, Bartrum, and Creed 2004).

Alongside demography, we believe educational characteristics are likely to be influential in the development of career management competency, consistent with Kuijpers and Meijers (2012) who report evidence of variations by degree specialisation and stage of study. We would expect elevated perceptions of capabilities in career management competencies among those later in their studies, assuming they have engaged with effective career development learning while at university. We also believe the influence of employment status is worthy of investigation.

\section{Method}

\section{Participants}

The sample comprises business undergraduates from 'young' and vocationally-focused universities in the UK $(N=136)$ and Australian $(N=344)$. The countries were selected on the basis of their explicit attention to developing student employability and the similarities in their labour market contexts. These include a broad acceptance among educators, government and industry that employability will contribute to economic well-being and that stakeholders are responsible for preparing graduates for the professional setting. Further, both countries, at 
the time of the survey, were experiencing similar labour market conditions with relatively high levels of graduate unemployment and underemployment (GCA, 2014; UKCES, 2015).

Participant characteristics are summarised in Table 1. The average age of the Australian and UK sample were significantly different $(p=.000)$ at 27 years and 22 years respectively. The higher proportion of mature-age students in the Australian university may be due to the choice of entry pathways into the university. There were relatively fewer females in the UK sample and a greater proportion of students in their final year of study. Variations exist in degree specialisation across the two samples and more Australian students were currently working although there were similar trends in the distribution of part-time and full-time status with, as expected, significantly more students working on a part-time basis. Relatively more UK students completed work placements as part of their studies. They participate in WIL under the sandwich degree model whereby two years of study is followed by one year of full-time work in industry, before returning to university for their final year. Students are ultimately responsible for securing their own one-year placements although support is provided by the university for advertising and guiding students to suitable opportunities. The Australian students complete shorter placements on a full or part-time basis over a 16 week period. Placements are organised by a dedicated WIL team within the Faculty. 
Table 1 Summary of participant characteristics

\begin{tabular}{|c|c|c|c|c|c|c|c|}
\hline \multirow[b]{3}{*}{ Variable } & \multirow[b]{3}{*}{ Sub-group } & \multicolumn{2}{|c|}{ Australia $(N=344)$} & \multicolumn{2}{|c|}{ UK $(N=136)$} & \multicolumn{2}{|c|}{ Total $(N=480)$} \\
\hline & & & & & & & Valid \\
\hline & & $\mathbf{N}$ & Valid \% & $\mathbf{N}$ & Valid \% & $\mathbf{N}$ & $\%$ \\
\hline \multirow[t]{4}{*}{ Age group } & Less than 20 years & 53 & 15.4 & 13 & 9.6 & 66 & 13.8 \\
\hline & 20 to 24 years & 138 & 40.1 & 111 & 81.6 & 249 & 51.9 \\
\hline & 25 to 29 years & 56 & 16.3 & 5 & 3.7 & 61 & 12.7 \\
\hline & 30 years and over & 97 & 28.2 & 7 & 5.1 & 104 & 21.7 \\
\hline \multirow{2}{*}{ Gender } & Male & 102 & 29.7 & 62 & 45.6 & 164 & 34.2 \\
\hline & Female & 242 & 70.3 & 74 & 54.4 & 316 & 65.8 \\
\hline \multirow[t]{7}{*}{ Specialisation } & Generalist & 32 & 9.3 & 21 & 15.4 & 53 & 11.0 \\
\hline & $\begin{array}{l}\text { Tourism, Hospitality, } \\
\text { Recreation and Events }\end{array}$ & 48 & 14.0 & 0 & 0.0 & 48 & 10.0 \\
\hline & $\begin{array}{c}\text { Marketing, Public } \\
\text { Relations and Advertising }\end{array}$ & 42 & 12.2 & 29 & 21.3 & 71 & 14.8 \\
\hline & $\begin{array}{c}\text { Human Resource } \\
\text { Management }\end{array}$ & 58 & 16.9 & 7 & 5.1 & 65 & 13.5 \\
\hline & Finance/Accounting & 104 & 30.2 & 12 & 8.8 & 116 & 24.2 \\
\hline & Management & 43 & 12.5 & 33 & 24.3 & 76 & 15.8 \\
\hline & Other & 17 & 4.9 & 34 & 25.0 & 51 & 10.6 \\
\hline \multirow[t]{3}{*}{ Stage of degree } & First year & 73 & 21.2 & 13 & 9.6 & 86 & 17.9 \\
\hline & Second year & 168 & 48.8 & 26 & 19.1 & 194 & 40.4 \\
\hline & Third year & 103 & 29.9 & 97 & 71.3 & 200 & 41.7 \\
\hline \multirow[t]{3}{*}{ Employment status } & Not currently working & 47 & 13.7 & 39 & 28.7 & 86 & 17.9 \\
\hline & Working part-time & 189 & 54.9 & 60 & 44.1 & 249 & 51.9 \\
\hline & Working full-time & 108 & 31.4 & 37 & 27.2 & 145 & 30.2 \\
\hline \multirow[t]{2}{*}{$\overline{\mathrm{WIL}}$} & Work placement & 58 & 16.9 & 52 & 38.2 & 110 & 22.9 \\
\hline & No work placement & 286 & 83.1 & 84 & 61.8 & 370 & 77.1 \\
\hline \multirow{3}{*}{$\begin{array}{l}\text { Host organisation } \\
\text { size }\end{array}$} & $1-49$ (small) & 26 & 44.8 & 10 & 19.2 & 36 & 32.7 \\
\hline & $50-149$ (medium) & 7 & 12.1 & 5 & 9.6 & 12 & 10.9 \\
\hline & $150+$ (large) & 25 & 43.1 & 37 & 71.2 & 62 & 56.4 \\
\hline \multirow{3}{*}{$\begin{array}{l}\text { Host organisation } \\
\text { sector }\end{array}$} & Public sector & 18 & 31.0 & 16 & 30.8 & 34 & 30.9 \\
\hline & Private sector & 29 & 50.0 & 36 & 69.2 & 65 & 59.1 \\
\hline & Not-for-profit & 11 & 19.0 & 0 & 0.0 & 11 & 10.0 \\
\hline
\end{tabular}

\section{Procedures}

We gathered data on the career management competencies of business undergraduates through self-assessment in an online survey. We invited business undergraduates from the two universities to participate in the study by email and/or via announcements on the universities’ virtual learning management system, between April and June 2014. 


\section{Measures}

We asked survey participants to initially report on their age, gender, degree major and stage of study. Details of their current employment status and whether they participated in a work placement as part of their undergraduate program were also required. While we acknowledge that WIL is an umbrella term encompassing a range of on and off-campus activities that integrate theory with practice (Patrick et al. 2009), we chose to measure WIL - for practical purposes - as the completion of a work placement.

We selected the DOTS career management framework for measuring career management competencies due to its concise nature, widespread use in the UK and suitability for the undergraduate cohort (Smith et al. 2009). The model is also considered valuable in assessing WIL experiences in regard to career management learning (Reddan and Rauchle 2012). McIlveen et al. (2011), who studied the perceived relationship between career development learning and WIL, argue the DOTS model 'clearly and simply captured student-related issues pertaining to the world-of-work, self-reflection, and transferability across learning and employment settings' (6). Twenty-one items were used to measure DOTS' four dimensions of self-awareness, opportunity awareness, decision-making learning and transition learning. These items have been used in previous empirical studies that assess career development learning among undergraduates based on the DOTS framework (see, for example, DacrePool, Qualter, and Sewell 2014; McIlveen et al. 2011; Reddan and Rauchle 2012). We asked participants to rate their capabilities in each item on a five-point scale, ranging from 'very poor' to 'very good'. In addition, we asked respondents to indicate, on a scale of one to five, the extent to which each item was developed during their work placement. A rating of 'one' specified no development and 'five' a high level of development. Finally, we asked respondents to consider which aspects of their work placement helped develop their career 
management competencies the most and to outline any barriers to their development. Both were optional, open-ended response questions.

\section{Analysis}

Items measuring the four dimensions of career management competency and the associated Cronbach alpha values are presented in Table 2. The values, each exceeding the widely accepted threshold value of .70 , confirm internal consistency among the constituent items/elements and their reliability as an accurate measure of that particular dimension. Correlations between the different items were computed to assess construct validity for each of the four dimensions. Values ranged from .65 to .89 , indicating the elements for a particular dimension are measuring the same facet of career management. 
Table 2 DOTS dimensions, means and standard deviations for capability and development during placement

Capabilities

Development

during placement

Item

a $\quad M \quad S D$

M 3.75 SD

Self-awareness

$81 \quad 4.01 \quad 51$

4.00

3.69

.75

Identify knowledge, abilities and transferable skills developed by one's degree

$\begin{array}{lll}4.15 & .65 & 3.99\end{array}$

Identify one's interests, values and personality in the context of vocational and life planning

Identify strengths and weaknesses, and areas requiring further development

$\begin{array}{lll}4.06 & .71 & 3.69\end{array}$

$\begin{array}{lll}4.08 & .73 & 4.07\end{array}$

4.07
3.55

Develop a self-reflective stance to academic work and other activities

Synthesise one's key strengths, goals and motivations into a rounded personal profile

Opportunity awareness

Demonstrate knowledge of general trends in graduate employment and opportunities for graduates in one's

discipline

Demonstrate understanding of the requirements of graduate recruiters

Demonstrate research-based knowledge of typical degree-related career options and options in which one is interested

Decision-making learning

Identify the key elements of career decision-making, in the context of life planning

Relate self-awareness to knowledge of different opportunities

Evaluate how personal priorities may impact upon future career options

Devise a short/medium-term career development action plan

Identify tactics for addressing the role of chance in career development

84

$\begin{array}{lll}3.88 & .76 & 3.48\end{array}$

3.88

Review changing plans and ideas on an ongoing basis

\section{Transition learning}

Demonstrate understanding of effective opportunity-search strategies

Apply understanding of recruitment/selection methods to applications

Demonstrate ability to use relevant vacancy information, including ways of accessing unadvertised

vacancies

Identify challenges and obstacles to success in obtaining suitable opportunities and strategies for addressing them

Demonstrate capacity to vary self-presentation to meet requirements of specific opportunities

Demonstrate ability to present oneself effectively in selection interviews and other selection processes

3.54

.80

3.55

$3.53 \quad 91 \quad 3.06$

1.01

0.94

1.05

0.96

1.08

1.06

$\begin{array}{llll}3.59 & .95 & 3.53 & 1.16\end{array}$

\begin{tabular}{lllll}
.83 & 3.80 & .63 & 3.60 & .63 \\
& 3.76 & .86 & 3.28 & 1.20 \\
& 3.89 & .81 & 3.40 & 1.12 \\
& 4.08 & .75 & 3.43 & 1.27 \\
& 3.75 & .97 & 3.44 & 1.15 \\
& 3.59 & .90 & 3.02 & 1.14 \\
& 3.75 & .81 & 3.30 & 1.22 \\
\hline & 3.77 & .63 & 3.63 & .59 \\
& 3.64 & .83 & 3.06 & 1.09 \\
& 3.87 & .90 & 3.41 & 1.25 \\
& 3.47 & .99 & 2.92 & 1.17 \\
& 3.65 & .86 & 3.26 & 1.11 \\
& 3.98 & .77 & 3.58 & 1.15 \\
& 4.03 & .80 & 3.67 & 1.21
\end{tabular}


Next, we examined the factor structure for each of the four DOTs dimensions for the UK and Australian cohorts to ensure there were no systematic differences across the samples and combining them was appropriate. We performed a factor analysis, using principal axis factoring (PAF) and direct oblimen rotation, to confirm the four DOTs dimensions for both the individual and combined samples. We identified a one-factor structure, for both the UK and Australian samples, for each of the four dimensions. The pattern of item-factor loadings was similar and ranged from .51 to .90 for the UK sample; .58 to .86 for Australian students and .55 to .86 for the combined sample. Invariance was demonstrated and the samples combined. We then conducted a descriptive analysis of career management competencies among the undergraduate sample $(N=480)$, followed by an evaluation of the variations in the four career management dimensions for the combined sample using MANOVA. We analysed the ratings assigned to the development of career management competencies during placement using descriptive techniques at both item and dimension level. Analysis was

conducted using SPSS 22.0. Finally, we completed a thematic analysis and coding at an individual response level of the open responses relating to aspects of work placements that assisted and hindered their development of career management competencies. This analysis was conducted using Excel. One hundred and four responses were gathered and analysed from the 110 students who had completed a work placement in both the UK and Australia.

\section{Results}

\section{Career management competencies among undergraduates}

The means and standard deviations of the four dimensions, and their constituent elements, are presented in Table 2. Self-awareness achieved the highest mean rating of 4.01, indicating that respondents - on average - consider themselves reasonably adept at identifying the knowledge and skills acquired during their degree and understanding their personal qualities, 
strengths and weaknesses in relation to the work context. They also embrace reflection and, overall, appear to recognise the importance of self-awareness. In contrast, they reported capabilities only marginally above average for opportunity awareness with a mean rating of 3.54. This indicates that respondents report limited knowledge of general trends in graduate employment, opportunities in their own prospective field of employment and the requirements of graduate recruiters. They have some understanding of degree-related career options but, again, with room for improvement.

Students performed marginally better in both decision-making learning and transition learning with mean ratings of 3.80 and 3.77 respectively. For decision-making learning, students rated themselves particularly well - with an average of 4.08 - on evaluating how their personal priorities may impact upon future career options, consistent with the reasonably high levels of self-awareness previously reported. Respondents were, however, less equipped with tactics for managing change in career development. Analysing transition learning at an item level would suggest that students perform better during the actual selection process - such as varying their self-presentation and conducting interviews - than the stage of actually seeking vacancies and identifying suitable opportunities. Accordingly, student scores for using relevant vacancy information and understanding effective opportunity-search strategies was relatively weak with mean ratings of 3.47 and 3.64 respectively.

\section{Influence of individual characteristics}

Significant MANOVA $(\alpha=.05)$ variations in competency ratings were reported for degree specialisation, $\lambda=.894, F(24,1640.844)=2.240, p=.001$, partial $\eta^{2}=.028$; stage of degree, $\lambda=.962, F(8,948)=2.307, p=.019$, partial $\eta^{2}=.019$; and employment status, $\lambda=.947, F(12$, 1251.732)=2.168, $p=.011$, partial $\eta^{2}=.018$. We did not detect significant results for age or 
gender. Significant interactions using univariate ANOVAs, with a Bonferroni correction $(\alpha=.013)$, are summarised in Table 3. Tukey post-hoc analysis indicated an effect for degree specialisation on transition learning with HRM students reporting significantly higher levels than those in Marketing ( $p=.006)$, Finance/Accounting $(p=.003)$, Management $(p=.032)$ and those in the Other grouping $(p=.005)$. Univariate analysis suggested that those working parttime typically achieved higher ratings than both those not working $(p=.035)$ and those working on a full-time basis $(p=.050)$. We found no evidence of a significant effect for stage of degree, despite the significant MANOVA.

Table 3 Analysis of variance in career management competencies by individual characteristics and participation in WIL

\begin{tabular}{|c|c|c|c|c|c|c|}
\hline Characteristic & Dimension & $d f$ & $M S$ & $\boldsymbol{F}$ & $p$-value & $\eta^{2}$ \\
\hline $\begin{array}{l}\text { Degree } \\
\text { specialisation }\end{array}$ & Transition learning & 6 & 1.378 & 3.549 & .002 & .043 \\
\hline $\begin{array}{l}\text { Employment } \\
\text { status }\end{array}$ & Opportunity awareness & 2 & 2.482 & 3.924 & .009 & .024 \\
\hline Work placement & $\begin{array}{c}\text { Self-awareness } \\
\text { Decision-making learning } \\
\text { Transition learning }\end{array}$ & $\begin{array}{l}1 \\
1 \\
1\end{array}$ & $\begin{array}{l}4.180 \\
5.706 \\
2.922\end{array}$ & $\begin{array}{c}16.377 \\
14.759 \\
7.389\end{array}$ & $\begin{array}{l}.000 \\
.000 \\
.007\end{array}$ & $\begin{array}{l}.033 \\
.030 \\
.015\end{array}$ \\
\hline
\end{tabular}

\section{Influence of WIL}

A significant MANOVA $(\alpha=.05)$ interaction was detected in competency ratings by participating in a work placement, $\lambda=.939, F(4,475)=7.710, p=.000$, partial $\eta^{2}=.061$. Significant ANOVAs $(\alpha=.013)$ for self-awareness, decision-making learning and transition learning are presented in Table 3. Comparative mean analysis indicated that, contrary to expectations, those not completing placements achieved significantly higher $(p=.000)$ mean ratings for self-awareness (4.06) than those who did (3.84). Similarly, non-placement students achieved higher ratings for decision-making learning $(p=.000)-3.86$ in comparison to $3.60-$ and transition learning $(p=.007)-3.81$ in contrast to 3.63 . 
We conducted further contingency analysis to investigate any mediating effect for employment status on ratings among placement/non-placement students. As suspected, filtering out those who were currently working in a full or part-time capacity produced a very different effect. The mean rating for all four dimensions of career self-management for those completing placements was higher than those who did not, although only significantly so $(p=.012)$ for decision-making learning (those completing placements achieved a mean rating of 3.87 in comparison to 3.44). It appears, therefore, that current employment status seems to wash out any positive effect of the work placement on certain career management competencies.

In relation to the extent to which the different career management competencies were developed during work placements, the mean ratings for each dimension - and their constituent elements - are presented in Table 2. Completing a work placement appeared to offer a reasonable opportunity for developing the four dimensions of career self-management. More specifically, students typically felt work placements were extremely useful for developing their ability to identify strengths and weaknesses and areas for future personal development. In addition, the data show relatively high ratings for placements' role in helping the student identify their interests, values and personality in the context of vocational and life planning. In contrast, placements assisted them less in developing a self-reflective stance and synthesising their attributes in a rounded profile. Reasonably high ratings were also achieved for opportunity awareness, decision-making learning and transition learning, suggesting work placements are - overall - a useful tool for cultivating career self-management capabilities among students. Inevitably, less evident was the capacity of placements to develop opportunity-search strategies among students, to improve understanding of general trends in 
graduate employment and degree-related career options, and more efficient use of vacancy information.

One hundred and four students identified aspects of the work placement that assisted them in developing their career management competencies. Our analysis identified six common themes in individual responses. First, many identified the development of self-awareness during their placement and gaining a better understanding of the skills required in their intended profession, the gaps need they needed to fill and where their personal strengths lie. One stated, 'the ability to talk with people that employ others to find out what skills would be required helped me greatly' (387). Another found by the end of the placement they were better able to 'synthesise one's key strengths, goals and motivations into a rounded personal profile' (195). Interestingly, several students noted that the recruitment process into the placement program (whether entirely within the placement provider or mediated via the university) helped to highlight what employers are looking for. This process is also likely to improve their confidence in the selection process. A number of respondents noted the quality and volume of constructive feedback, which often extended beyond that provided at university, was invaluable to deciphering their personal weaknesses and areas for improvement.

Second, many cited the mere exposure to working first-hand in their chosen profession as invaluable to their career planning skills and in providing insight into the realities of the industry. Third, working alongside established professionals allowed them to learn through listening and interaction, as well as the guidance and mentoring they received. Two students commented on what they learned from watching professionals promote themselves in their careers among their peers and colleagues. Fourth, many felt the placement experience had 
enhanced their confidence in their own capabilities to perform at the required level. One stated, '[the] placement has helped me push boundaries to make me more confident in my abilities and see where I can progress to' (374). Several believed they had progressed with career planning: 'it allowed me to gain a thorough understanding of what path I need to take' (257). Finally, many felt the placement helped them learn about networking and also provided them with opportunities to improve their own networks, gaining 'first-hand experience in meeting existing clients/partners and interacting with potential new partners/contacts for future employer prospects' (415).

Our thematic analysis identified six main barriers to developing career management competencies during the work placement experience. The first was a lack of exposure to their chosen profession through poor placement design. Some students felt work placements, in this instance one hundred hours in duration, were too short and others were based in a work area unrelated to their degree specialisation or were working in isolation from the rest of the department. A second barrier was a lack of mentoring and guidance. Some students found managers unsupportive of the placement process or the assigned mentor lacked knowledge of their targeted profession. A small number commented on the lack of formal training given in the workplace and they felt there was a heavy reliance on learning by themselves and through their own mistakes.

Certain individual characteristics inhibited the development of career management competencies. Younger students noted the age gap with members of staff contributed to a lack of trust in their judgment and those with weaker English language skills could also not glean full benefit from their placement. One student noted that diversity, in general, acted to create misunderstanding that, in turn, inhibited learning. Several commented on the importance of 
communication and confidence in personal development during the placement. Finally, host organisation type appeared to influence the development of career management with larger organisations facilitating rotation across different areas, highly beneficial for broadening a student's understanding of their intended profession, and providing a wider range of work programs and projects for students to complete. As an aside, many students spoke about their inability to 'shine' during the placement due to their lack of responsibility and control over the work undertaken, a situation aggravated on short placements.

\section{Discussion/Implications}

Our data show that business undergraduates differentially rate themselves on their possession of particular career management competencies. On average, students perceive their competency in opportunity awareness relatively lower than decision-making and transition learning. The work placement appears to offer a sound platform for developing self-awareness among students, consistent with previous studies exploring the value of WIL (Jackson 2013). WIL also appears to positively impact on the development of opportunity awareness, decision-making learning and transition learning. An area of weaker development among WIL students was nurturing opportunity-search strategies and a broader understanding of the graduate labour market. Overall, the data suggests that, certainly in the absence of concurrent part-time or full-time employment, students benefit from work placements in the development of career management competencies. This is consistent with the findings of Kuijpers and Meiers (2011) who report that a 'career-oriented learning environment' that stimulates the development and application of career competencies is one in which students have the opportunity to obtain real-life work experience. That work experience per se appears to contribute to greater possession of career management competencies, whether integrated into 
a program of study or not, reinforces the value of all employment to student and graduate employability.

The implications of this data for HE institutions are twofold. First, they reinforce the imperative to expand opportunities for WIL across the student population. Within the sample, notably reflecting differences in the experience of the UK and Australian cohorts, students experience different forms of WIL from year-long industrial placements to shorter, less intensive periods of work experience, That the data indicates the influence of WIL across the two cohorts on the development of critical career management competencies suggests the value of diverse forms of WIL. This supports evidence (for example, Jain and Jain 2013; Wilton 2012) for the positive impact of WIL for the development of critical employmentrelated capabilities and attributes. It also adds nuance to the question of exactly how WIL contributes to employability. As such, HE providers need to be proactive in promoting and securing employment opportunities for students, particularly among those social groups that continue to experience disadvantage in the graduate labour market and in those subject areas where WIL has historically been less commonplace.

Second, the data indicates that WIL is not a panacea for the development of such competencies. The data shows that development is not uniform across competencies and, notably for the development of career-search strategies and labour market understanding, HE providers have a critical role in situating work experience within the broader environment in which such capabilities are enacted. WIL is reported by respondents to clearly have an impact on 'inward-focused' competencies, yet, not surprisingly, a lesser impact on 'outward-focused' contextualisation of experience. As such, universities have a critical role to play before, during and after WIL activities to place experience in its broader context through individual 
counselling, provision of relevant information and group briefings. This is likely not only to ensure students possess a better understanding of the graduate labour market, both in general and relating to specific sectors or occupations, but also to improve their preparedness for, and confidence during, selection processes. The development of contextual understanding should begin at the outset of study so that subsequent WIL can be used as to prompt to reflection upon this experience within the context of career intentions and to shape the development of career development strategies.

For employers, the key message from the data is that, in order to best address their own criticisms of the graduate labour supply, recruiters should proactively provide opportunities for students to develop career management and related competencies through WIL. As employers seek means by which to secure talent and engage in non-standard ways of doing so, such as curriculum co-design and early identification of potential recruits, then a critical means of positively shaping prospective employees, as well as a means of screening possible applicants for graduate posts, is to offer opportunities for work experience.

While the positive benefits of work experience during study are well rehearsed, take up among students, certainly in the UK, remains patchy (Bullock et al. 2009). This data adds further weight to arguments concerning work experience as being central to the enhancement of individual employability. That current students often remain sceptical of the benefits of WIL represents a critical challenge for HE providers, further reinforcing the need to be able to clearly advise students of the specific benefits of work placements and the manner in which WIL positively impacts employability. This research contributes to this discourse by elucidating the specific areas in which WIL students are better prepared for the graduate labour market beyond the acquisition of work-related skills and experiences (Wilton 2012). 
Interestingly, that the data provides no evidence for a gender or age effect on the development of career management competencies reinforces the perspective that work experience is the prime determinant of the possession of employability-related attributes and, therefore, adds weight to the view that WIL has a role to play in overcoming traditional social disadvantage in the graduate labour market (Wilton 2011). The absence of a 'stage of study' effect in the analysis is also worthy of note. It might be assumed that students who are further progressed in their studies would report higher levels of competency development. That this is not the case indicates again that work experience represents a key determinant of attainment of such competencies. It also suggests that HE providers have work to do to ensure the progressive development of competencies, particularly among those who do not choose or have the opportunity to undertake WIL.

Developing career management competencies in a campus-setting, for those who participate in WIL and those who do not, should emphasise fostering effective opportunity search strategies. This may include enhancing student understanding of trends in graduate employment, as well as the importance of keeping up to date with these. One way of achieving this is regular 'employment seminars' where external stakeholders inform students of trends in their local economy and how these translate to areas of growth, or decline, in the graduate and broader labour market. Seminars could be delivered by graduate economists through, for the example, the local chamber of commerce and industry which are typically keen to support university members. Similarly, developing student understanding of how to use vacancy information more efficiently and the expectations of graduate employers could be managed through guest lectures and/or seminars from HRM managers with extensive experience in graduate recruitment, preferably across different organisations and sectors. 
Introducing students to industry requirements and the latest techniques for assessing graduate applicants against these selection criteria would be particularly useful. Finally, broadening student thinking in relation to degree-related career options could be achieved by emphasising the importance of small and medium businesses as graduate employers and the less 'popular' choices for graduate employment, such as the retail sector. This may encourage students to think more innovatively about where to seek work, beyond the traditional and highly sought after graduate programs. Finally, assigning academic credit for career development learning, whether embedded in management, HR or organisational behaviour units or through standalone delivery, could enhance student competency in harnessing the ever important hidden job market and, more broadly, developing effective skills in career self-management.

\section{Conclusion}

This study develops our understanding of how undergraduates perform in career management competencies and the impact of WIL, more specifically work placements, on individual's knowledge, skills and abilities relating to career management. Undergraduates consider themselves reasonably proficient in career management competencies, particularly in the area of self-awareness. There is, however, room for improvement and particularly in their ability to identify suitable opportunities, understand employer expectations and demonstrate awareness of graduate and career-specific employment trends. Notably, respondent's degree specialisation and employment status caused variations in competency ratings for certain aspects of career self-management. We found participation in work placements was also influential although this effect appeared to be washed out for those currently in employment. Those completing work placements broadly believed them useful to the development of career management competencies, particularly self-awareness. 
Key areas in which WIL promoted career development learning included the ability to selfassess work-related capabilities, insight into the realities of a profession, exposure to guidance and mentoring by established professionals, enhanced confidence, and career planning and networking. Impediments to the development process included a lack of exposure to their intended profession through poor placement design, poor mentoring and guidance, low selfesteem and poor communication.

We aimed to advance understanding of how career management competencies are cultivated in undergraduates through WIL. There is limited empirical analysis gauging career management competencies among undergraduates and how best to develop them, particularly in relation to infrastructure, funding and collaborative partnerships among relevant stakeholders (Watts 2006). Our findings highlight the pivotal role of student work placements for career development learning and suggest a set of strategies for practitioners to enhance career management provision and, ultimately, graduate employability. This will assist in producing graduates whom are aware of their career aspirations, more able to pursue their career goals and which can make informed career choices and confidently transition to the graduate labour market with a clear understanding of available pathways and opportunities. This is critical, given the expectation that today's graduates will have relevant work experience, a repertoire of key skills and notable achievements, and a clear understanding of their career goals (GCA 2012).

As with all studies, ours has limitations. The study only explores individual-level influences on career management competencies and does not extend to social/cultural capital explanations. Many, for example, acknowledge the influence of social class (Greenbank 2011), ethnicity (Kuijpers and Meijers 2012) and media, social and political climate 
(Blackford 2010). We gathered self-report data, which is considered problematic by some (Douglass, Thomson, and Zhao 2012), using a single method that may raise concerns for common method variance (Taylor 2014). An alternative approach to gathering student perceptions could be the objective assessment of career management competencies by career management providers in the university setting. Also, we allow no comparative analysis of different strategies used to develop career management competencies in undergraduates as this study focuses on only one aspect of WIL, namely work placements. Future studies could also explore the influential role of personality (see Gerber et al. 2009). 


\section{References}

AAGE. 2013. 2013 AAGE employer survey. Sydney, Australia: Australian Association of Graduate Employers.

Accenture. 2013. College graduate employment survey. US: Accenture.

Adamson, S., N. Doherty, and C. Viney. 1998. "The meaning of career revisited: implications for theory and practice". British Journal of Management 9 (4): 251-9.

AGCAS. 2005. Careers Education Benchmark Statement. Sheffield, UK: Association of Graduate Careers Advisory Services.

AGR. 2013. AGR graduate recruitment survey 2013 (Winter Review). London, UK:

Association of Graduate Recruiters.

Akkermans, J., V. Brenninkmeijer, R. Blonk, and L. Koppes. 2013. "Fresh and

healthy? Well-being, health and performance of young employees with intermediate education". Career Development International 14 (7): 671-699.

Akkermans, J., W. Schaufelia, V. Brenninkmeijer, and R. Blonk. 2013. "The role of career competencies in the Job Demands-Resources model". Journal of Vocational Behaviour 83 (3): 356-366.

Ashby, J. and I. Schoon. 2010. "Career success: The role of teenage career aspirations, ambition value and gender in predicting adult social status and earnings". Journal of Vocational Behavior 77 (3): 350-360.

Ayranci, E. and E. Oge. 2011. "A Study of the Relationship between Students' Views toward A Career Management Class and Their Future Careers". International Business Research 4 (1).

Benson, V., S. Morgan, and F. Filippaios. 2014. "Social career management: Social media and employability skills gap". Computers in Human Behavior 30: 519-525.

Berdrow, I. and F. Evers. 2011. "Bases of competence: A framework for facilitating reflective learner-centered educational environments". Journal of Management Education 35 (3): 406427.

Berntson, E. and Marklund S. 2007. "The relationship between perceived employability and subsequent health". Work \& Stress: An International Journal of Work, Health \& Organisations 21 (3): 279-292.

Blackford, S. 2010. "A qualitative study of the relationship of personality type with career management and career choice preference in a group of bioscience postgraduate students and postdoctoral researchers". International Journal for Researcher Development 1 (4): 296-313. Bourner, T. and J. Millican. 2011. "Student-community engagement and graduate employability". Widening Participation and Lifelong Learning 13 (2): 68-85.

Bridgstock, R. 2009. “The graduate attributes we've overlooked: Enhancing graduate employability through career management skills". Higher Education Research and Development 28 (1): 31-44.

Brown, P. and A. Hesketh. 2004. The Mismanagement of Talent-Employability and Jobs in the Knowledge Economy. Oxford, UK: Oxford University Press.

Bullock, K., V. Gould, M. Hejmadi and G. Lock. 2009. "Work placement experience: should I stay or should I go?" Higher Education Research \& Development 28 (5): 481-494.

Cleary, M., J. Horsfall, P. Muthulakshmi, B. Happell and G. Hunt. 2013. "Career development: graduate nurse views". Journal of Clinical Nursing 22 (17-18): 2605-2613.

Coetzee, M. and C. Beukes. 2010. "Employability, emotional intelligence and career preparation support satisfaction among adolescents in the school-to-work transition phase". Journal of Psychology in Africa 20 (3): 43-446. 
Crebert, G., M. Bates, B. Bell, C. Patrick, and V. Cragnolini. 2004. "Developing generic skills at university, during work placement and in employment: graduates' perceptions". Higher Education Research and Development 23 (2): 147-165.

Creed, P., L. Prideaux, and W. Patton. 2005. "Antecedents and consequences of different decisional states in adolescence: A longitudinal study". Journal of Vocational Behavior 67 (3): $397-412$.

Dacre Pool, L. and P. Sewell. 2007. "The key to employability: Developing a practical model of graduate employability". Education + Training 49 (4): 277-289.

Lorraine, D., P. Qualter, and P. Sewell. 2014. "Exploring the factor structure of the CareerEDGE employability development profile". Education \& Training 56 (4): 303-313. Davey, A. and L. Tucker. 2010. "Enhancing higher education students' employability and career management: A library service approach". Library Review 59 (6): 445-454.

de Janasz, S. and M. Forret. 2007. "Learning the art of networking: A critical skill for enhancing social capital and career success". Journal of Management Education 32 (5): 629650.

Department of Industry. 2013. Strategic Research Priorities. Canberra, Australia: Department of Industry.

Douglass, J., G. Thomson, and C. Zhao. 2012. "The Learning Outcomes Race: The Value of Self-reported Gains in Large Research Universities". Higher Education 64 (3): 317-35. Eby, L., M. Butts, and A. Lockwood. 2003. "Predictors of Success in the era of the boundaryless career". Journal of Organizational Behavior 24 (6): 689-708.

Evans, C. 2008. "Developing career management skills within the HE curriculum: A review and evaluation of different approaches". The International Journal of Management Education 6 (3): 45-55.

GCA. 2012. Graduate Outlook 2012: the report of the Graduate Outlook Survey. Parkville, Australia: Graduate Careers Australia.

GCA. 2014. Employment for new graduates: slow but steady. Melbourne: Graduate Careers Australia.

Gerard, J. 2012. "Linking in with LinkedIn®: Three exercises that enhance professional social networking and career building”. Journal of Management Education 36 (6) 866-897.

Gerber, M., A. Wittekind, G. Grote, and B. Staffelbach. 2009. "Exploring types of career orientation: A latent class analysis approach". Journal of Vocational Behavior 75 (3): 303 318.

Greenbank, P. and S. Hepworth. 2008. Working Class Students and the Career Decisionmaking Process: a Qualitative Study. Manchester, UK: HECSU.

Greenbank, P. 2011. "Improving the process of career decision making: an action research approach". Education + Training 53 (4): 252-266.

Greenhaus, J., G. Callanan, and V. Godshalk. 2009. Career management. Thousand Oaks, CA: Sage Publications.

Gunn, V. and K. Kafmann. 2011. Employability and the austerity decade. Graduates for the 21st Century: Integrating the Enhancement Themes. Glasgow, Scotland: Quality Assurance Agency.

Hawkins, P. and J. Winter. 1995. Skills for Graduates in the 21st Century. Cambridge, UK: Association of Graduate Recruiters.

Heaton, N., M. McCracken and J. Harrison. 2008. "Graduate recruitment and development: Sector influence on a local market/regional economy". Education + Training 50 (4): 276-288. Holmes, L. 2001. "Reconsidering Graduate Employability: the 'graduate identity' approach". Quality in Higher Education 7 (2): 111-119.

Holmes, L. 2013. "Competing perspectives on graduate employability: possession, position or process?" Studies in Higher Education 38 (4): 538-554. 
Hooley, T., A. Watts, R. Sultana, and S. Neary. 2013. "The 'Blueprint' framework for career management skills: a critical exploration”. British Journal of Guidance \& Counselling 41 (2): 117-131.

IEAA. 2012. Internships and work placement opportunities for international students in Victoria. Melbourne, Australia: International Education Association of Australia.

Isherwood, S. 2014. The Graduate Labour Market in 2014. Presentation at the Employability Summit, University of Leicester, December $18^{\text {th }} 2013$.

Jackson, D. 2013. "The contribution of work-integrated learning to undergraduate employability skill outcomes". Asia-Pacific Journal of Cooperative Education 14 (2), 99-115. Jackson, D. 2014. "Employability skill development in work-integrated learning: Barriers and best practice". Studies in Higher Education 40 (2): 350-367.

Jain, R. and S. Jain. 2013. "Conceptualization, Measure Development and Empirical Assessment of Career Oriented Attitudes and Employability of Technology Graduates". Vision: The Journal of Business Perspective 17 (2): 143-157.

King, Z. 2004. "Career self-management: Its nature, causes and consequences". Journal of Vocational Behavior 65 (1): 112-133.

Krug, G. and M. Rebien. 2011. Job search via social networks: an analysis of monetary and nonmonetary returns for low-skilled unemployed. Discussion Paper No. 201123. IAB.

Kuijpers, M. and F. Meijers. 2012. "Learning for now or later? Career competencies among students in higher vocational education in the Netherlands". Studies in Higher Education 37 (4): 449-467.

Laker, D. and R. Laker. 2007. "The five-year resume: A career planning exercise". Journal of Management Education 31 (1): 128-141.

Maertz, P., P. Stoeberl and J. Marks. 2014. "Building successful internships: lessons from the research for interns, schools, and employers". Career Development International 19 (1): 123 142.

McIlveen, P., S. Brooks, A. Lichtenberg, M. Smith, P. Torjul and J. Tyler. 2011. "Perceptions of career development learning and work-integrated learning in Australian higher education". Australian Journal of Career Development 20 (1): 32-53.

McKeown, T. and M. Lindorff. 2011. "The graduate job search process-a lesson in persistence rather than good career management?" Education + Training 53 (4): 310-320. Miller, S. and R. Liciardi. 2003. "Tertiary student perceptions of the benefits of professional career management education: An exploratory study". Career Development International 8 (6): 309-315.

Ng, E. and R. Burke. 2006. "The next generation at work - business students' views, values, and job search strategy". Education + Training 48 (2): 478-92.

Orrell, J. 2011. Good Practice Report, Work-integrated learning. Sydney, Australia: Australia Learning and Teaching Council.

Patrick, C., D. Peach, C. Pocknee, F. Webb, M. Fletcher, and G. Pretto. 2009. The WIL (Work Integrated Learning) report: A national scoping study, final report. Brisbane, Australia:

Queensland University of Technology.

Patton, W., D. Bartrum, and P. Creed. 2004. "Gender differences for optimism, self-esteem, expectations and goals in predicting career planning and exploration in adolescents". International Journal for Educational and Vocational Guidance 4 (2-3): 193-209. Pegg, A., J. Waldock, S. Hendy-Isaac, and R. Lawton. 2012. Pedagogy for employability. York, UK: Higher Education Academy.

Perrone, L. and M. Vickers. 2003. "Life after graduation as a very uncomfortable world: An Australian case study”. Education + Training 45 (2): 69-78. 
Peterson, G., J. Sampson, and R. Reardon. 1991. Career Development and Services: A Cognitive Approach. Pacific Grove, CA: Brooks/Cole.

Potgieter, I. 2012. "The relationship between the self-esteem and employability attributes of post-graduate business management students". SA Journal of Human Resource Management $10(2): 1-15$.

Purcell, K., P. Elias, G. Atfield, H. Behle, R. Ellison, and D. Luchinskaya. 2013. Transitions into employment, further study and other outcomes. Warwick, UK: Warwick Institute of Employment Research.

Raemdonck, I., H. Tillema, A. de Grip, M. Valcke, and M. Segers. 2012. "Does selfdirectedness in learning and careers predict the employability of low-qualified employees?" Vocations and Learning 5 (2): 137-151.

Raelin, S., M. Bailey, J. Hamann, L. Pendleton, J. Raelin, J. Rilsberge, and D. Whitmanm. 2011. "The Effect of Cooperative Education on Change in Self-Efficacy among Undergraduate Students: Introducing Work Self-Efficacy". Journal of Cooperative Education \& Internships 4 (2): 17-35.

Reddan, G. and M. Rauchle. 2012. "Student perceptions of the value of career development learning to a work-integrated learning course in exercise science". Australian Journal of Career Development 21 (1): 38-48.

Ross, J. 2012. "\$3bn hit to economy as foreign students slump”. The Australian, March 07. Sagdic, M. and H. Demirkaya. 2009. "The views of university students about career development plans”. Erciyes Üniversitesi Sosyal Bilimler Enstitüsü Dergisi 26: 233-246. Segers, J. and I.Inceoglu. 2012. "Exploring supportive and developmental career management through business strategies and coaching". Human Resource Management 51 (1): 99-120. Smith, C. 2012. "Evaluating the quality of work-integrated learning curricula: A comprehensive framework". Higher Education Research and Development 31 (2): 247-262. Smith, M., S. Brooks, A. Lichtenberg, P. McIlveen, P. Torjul, and J. Tyler. 2009. Career development learning: maximising the contribution of WIL to the student experience. University of Wollongong, Careers Central, Academic Services Division: ALTC.

Smith, E. and J. Kruger. 2008. "A critical assessment of the perceptions of potential graduates regarding their generic skill level: An exploratory study". SAJEMS NS 11 (2): 121-138. Smith, C. and K. Worsfold. 2013. "WIL curriculum design and student learning: a structural model of their effects on student satisfaction". Studies in Higher Education 39 (6): 10701084.

Stevenson, J. and S. Clegg. 2011. "Possible selves: students orientating themselves towards the future through extracurricular activity”. British Educational Research Journal 37 (2): 231246.

Sultana, R. 2012. "Learning career management skills in Europe: A critical review". Journal of Education and Work 25 (2): 225-248.

Taylor, S. 2014. "Student self-assessment and multisource feedback assessment: Exploring benefits, limitations and remedies". Journal of Management Education 38 (3): 359-383. Tomlinson, M. 2012. "Graduate employability: A review of conceptual and empirical themes". Higher Education Policy 25 (4): 407-421.

UKCES. 2015. Growth through people: Evidence and analysis. Wath-upon-Dearne, UK: UK Commission for Employment and Skills.

Usher, A. 2012. "Measuring Work Integrated Learning: The development of the Metacompetency Test”. Journal of Cooperative Education \& Internships 46 (1): 5-15.

Varghese, M., L. Carleton Parker, O. Adedokun, M. Shively, W. Burgess, A. Childress A., and A. Bessenbacher. 2012. "Experimental internships: Understanding the process of student learning in small business internships". Industry and Higher Education 26 (5): 357-369. 
Watts, A. 2005. "Career guidance policy: an international review". Career Development Quarterly 54 (1): 66-76.

Watts, A. 2006. Career development learning and employability. Learning and Employability Series Two. York, UK: ESECT and HEA.

Whitelaw, P. 2010. Re-conceptualising hospitality management: Analysing and predicting career progression and success in hospitality (PhD thesis, Victoria University).

Wilton, N. 2011. "Do employability skills really matter in the graduate labour market? The case of business and management graduates". Work, Employment and Society 25 (1): 85-100 Wilton, N. 2012. "The impact of work placements on skills development and labour market outcomes for business and management graduates". Studies in Higher Education 37 (5): 603620.

Zhang, Y. 2010. Recent tertiary graduates' career attitudes, career adaptability and career self-management behaviours: Focus on continuity in a fragmented employment context. Unpublished thesis. 